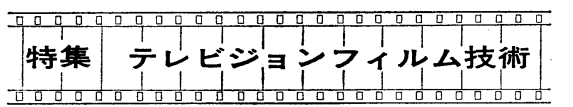

\title{
フィルム用ビジコンカメラ系の特性改善 と自動化
}

八欧電機株式会社

$\begin{array}{lll}\text { 石 原 } & \text { 豊 } \\ \text { 金 岡 隆 }\end{array}$

\section{1. まえがき}

フィルムビジコン系の自動化は二つの方向から考察す ることができる.一つはテレビ局全般あるいはテレシネ 室の自動化計画の一環として推進されている自動化であ り，むう一つは，ビジコンカメラ単体自身の自動化であ る.この二つは互いに関係はあるが，前者においてはフ ィルムのスタート, ストップ, マルチプレクサチェンジ などの自動化，番組編成を容易にするためのカメラと映 写機の $1: 1$ 機構採用, 故障時のヘッド予備との一挙動 切り替えなど，後者に抏いては ALC, AGC, ASU, ASC などが考えられる。一方，自動化之同時に最近は 画質改善が叫ばれ，フィルムビジコンカメラ系に関係す る各部門がそれぞれの立場に立って改善策を発表してい る. カメラ自体についてあセパレートメッシュの1イン チビジコン 8507，11/1/2 インチビジコン 8051 の採用に より, 高解像度の画像を得るととが可能になり, そのほ か, 垂直アパーチャ一補正器1), I.O. カメラ近似画質補 償器2などの実験が行なわれている.

\section{2. ビジコンの特性について}

現在，フィルム送像用ビジコンカメラ装置に使用され ているビジコンは, 大半が1インチであるが, 画質改善 に伴い11/2亿ンチあ実用されてきた。 11/2亿ンチビジコ ンの特長としては, ターゲット面が大きいため, 走査ビ 一ムによる解像度の限界が上がり, ターゲットでの光の 散乱による解像度の低下がなくなり, 強い集束磁界之高 い加速電圧により収差が減少し, 高解像度(中心部 1200 本）の画像を得ることができるようになった. 図 1 は 1インチ怙よび $11 \frac{1}{2}$ インチの解像度を示す.

しかし，11/2インチにしたために発生する問題点む多

"Automatic Operation and Characteristic Improvement of Vidicon Camera Chain for Film" by Yutaka Ishihara and Takao Kanaoka (Yaou Electric Co. Ltd., Kawasaki)

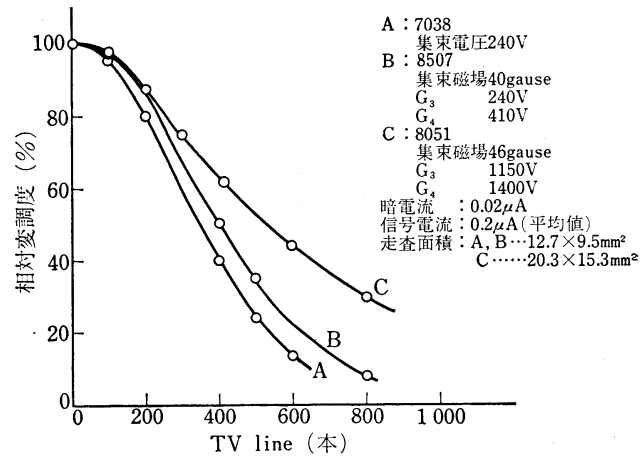

図 $17038,8507,8051$ の変調度特性

く，第一にターゲット面を大きくしたために容量す大き くなり，残像が長くなるためビーム電流を多く必要とす る. 容量を減らすには光導電体を厚くすれば減るが，そ うすると光の散乱による解像度の低下や, 感度の低下が 起きる，また，信号出力を多くするてとは残像を減らす ことに役立つが，そのためにビームを增さなければなら ないので，ビームが太くなる可能性がある．測定の結果 によれば，容量性残像よりも光導電性の残像のほうが問 題)之なり，ビームの太さとか祖合わせてある点で妥協 せざるを得ない８051は残像が最小になるように設計さ れているため, 感度を多少犠牲にしている. 実際に8051 を使用した場合の残像特性を図 2 亿示す.

また，11/2 インチビジコン8051はフィールドメッシュ $\left(\mathrm{G}_{4}\right)$ と集束電極 $\left(\mathrm{G}_{3}\right)$ が従来の1インチビジコンと異な り分離されているため, フィールドメッシュによりビー ムの半径方向の速度成分が補正できるので, 偏向コイル をターゲットの近くまであっててられる. 1インチビジ コンはこれができず, 偏向コイルを離さなければならな かったために，Sひずみを生ずる傾向があったが，8051 はこれがなくなっだ!．一方， $\mathrm{G}_{3}, \mathrm{G}_{4}$ 電極にかける電圧 比を適当に選ぶことにより，ビームランディング特性を 
良くすることができるので，シェーディングのない映像 信号を得ることができる.

8051のアセンブリーは，解像度を良くするために，電 磁偏向と長い電磁集束コイルを採用している. ビームの 長さは球面収差除去のためには短いほうがよく, ビーム の偏向ひずみを減らすには長いほうがよいので, 両者を 考慮して，その間の妥協点をとって決定している. 図3 㹥, $\mathrm{G}_{3}, \mathrm{G}_{4}$ 電極の比によるシェーディングの模様を示し

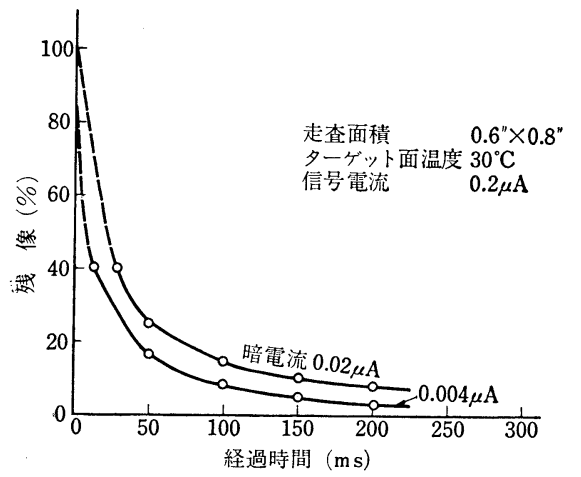

図 28051 の残像特性

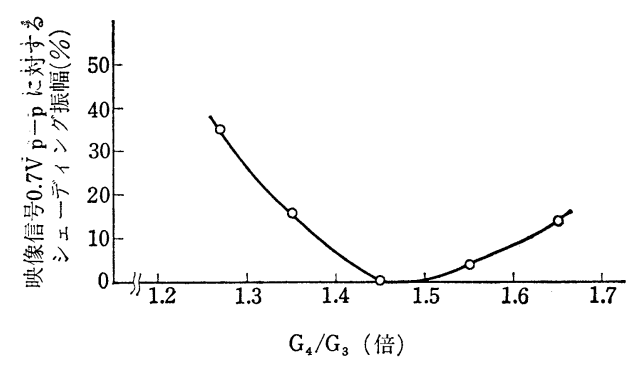

図 $3 G_{3}, G_{4}$ 電極飞対するシェーディング特性

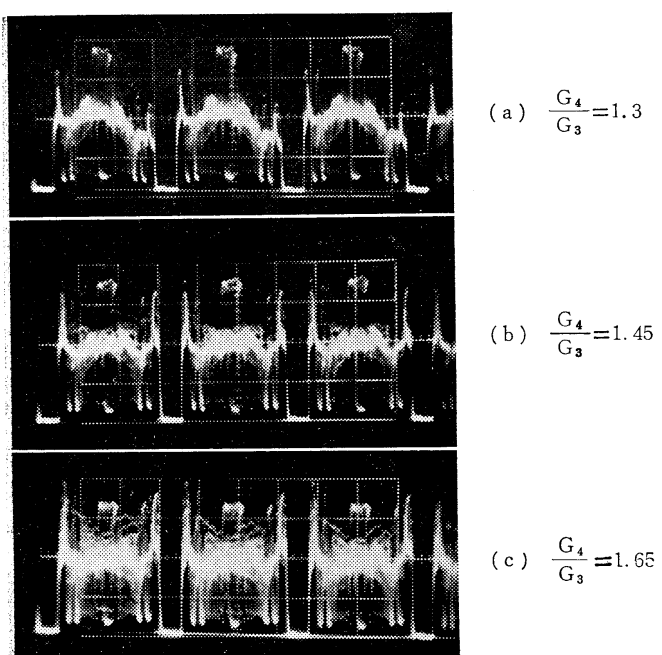

写真 1 シェーディングの映像出力波形
たものである.また, 写真 1 は映像出力におけるシェー ディングの状態を示す.

セパレートメッシュタイプを採用した1インチビジコ ン 8507 が発表されて以来，11/2インチと同様その性能が 認められ, 現在では従来の 1 インチビジコン 7038 に代 わって使用されているが, 構造的には電極構造が変わっ ただけで他は7038と同一である.

\section{3. 画質補償器}

ビジコンカメラの画質改善を行なう目的の一つとして イメージオルシコンカメラの画像の途中にビジコンカメ ラの画像が挿入された場合，その画質に異質感が大きい ことが上げられる. 従来ビジコン管の改良, アパーチャ 一補償 (水平), プリアンプの $S N$ 比 $^{5)}, \gamma$ 補正などが行 なわれてきたが，イメージオルシコンの画像と比較すれ ば，まだまだ改善の余地があり，そのためにイメージオ ルシコンの画像に近似させるために種々の回路が実験さ れ, 発表されている. また, 性質は多少異なるが, 垂直 アパーチャー補正回路 ${ }^{1)}$ がすでに実験されて好結果を得 ている.

\section{4. フォーカスの安定度}

ビジコンカメラの自動化を行なう場合, 高度の安定度 が要求されるが, その中でもフォ一カス関係の電圧, 電 流はその変動が画像に与える影響が大きいため, とくに 注意しなければ最良の画像を得ることができない.

図 4 は 8051 に抽い $\mathrm{G}_{3}, \mathrm{G}_{4}$ 電極電圧を一定にしたと き, フォーカスコイルに流れる電流の変動による解像度 を示したもので, この図から判断すれば，解像度 350 本 のアパーチャーレスポンスを70\%に保持するためには， 電流の許容変動は約土 $2 \%$ に押えなければならない.

同様に図 5 はフォーカスコイルに流れる電流を一定に 保ち, $\mathrm{G}_{3}, \mathrm{G}_{4}$ 電極電圧の变動に対する解像度を示したも

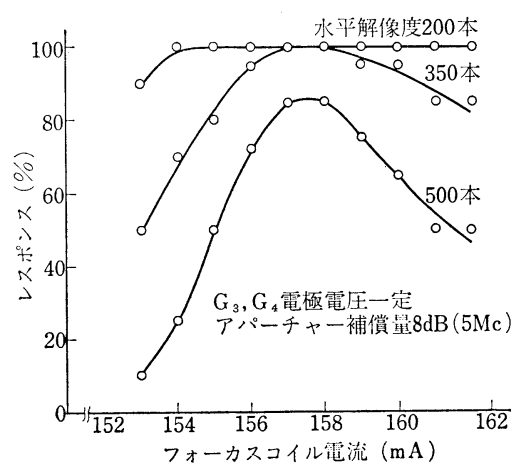

図 4 フォーカスコイル電流の 変動飞対する解像度 


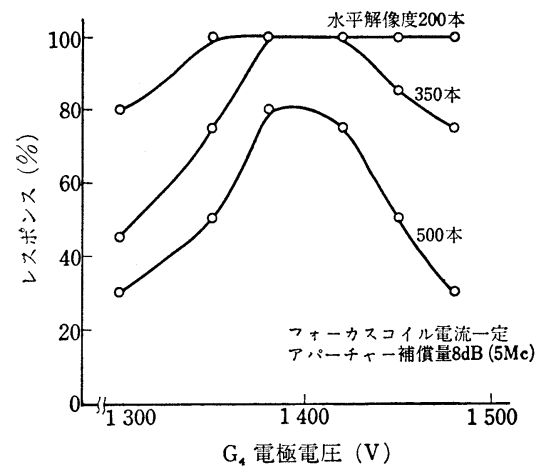

図 5 電極電圧の変動飞対する解像度

のであるが, これより変動率は約 $3 \%$ まで許容できる. 以上はおのおの単独に変動する場合を考えたが，これら が同時に変動すれば，以上の值よりむむっと箃密に押え る必要がある.

実際の機器に使用されている電源を例にとれば, フォ 一カスコイル電流源は電流安定化回路を使用することに より, $0^{\circ} \sim 40^{\circ} \mathrm{C}$ の範囲で変動率を $\pm 0.7 \%$ 以内にするこ とができ，一方 $\mathrm{G}_{3}, \mathrm{G}_{4}$ 電極電圧す $\pm 2 \%$ 以内に押える ことができるため，8051を使用した場合にはフォーカス の無調整化を行なうことができる.

\section{AGC}

AGC 回路はビジコンカメラ装置の映像出力段以後に 入れる場合と, プロセスアンプの途中に入れる場合があ り，現在ではその両者が使用されている. 前者はビジコ ンカメラにかぎらず使用できるので, 単独機器として取 扱うことができるが，後者を使用する場合は制御回路の 検出点および ASU との関係があり，その取扱いには注 意を要する.

図 6 はトランジスタ化ビジコンカメラに使用されてい るAGC, ASU 回路の系統図で, 検出点は ASU と同一 点から取り出し，それぞれの制御を行なっている. 利得 調整を行なう回路としては，ダイオードの逆電圧電流特 性領域のインピーダンス変化を利用している.

一般に, ダイオードの微小変化に対する等価抵抗は,

$$
\begin{aligned}
& R_{d}=\frac{d E}{d I}=\frac{1}{A k} \varepsilon^{-k E} \\
& \quad(A k \text { はダイオードによる定数) }
\end{aligned}
$$

となり，ダイオードの両端に加わる電圧を変化すれば利 得調整を行なうととができるが，ダイオードの両端には 交流分も加わるので，映像信号に対して直線性が悪くな る.

これに対し図 $7^{6)}$ のようにダイオードを 2 個使用した 場合は，E を変えると $I=A \cdot \exp (k E / 2)$ となり, 次に

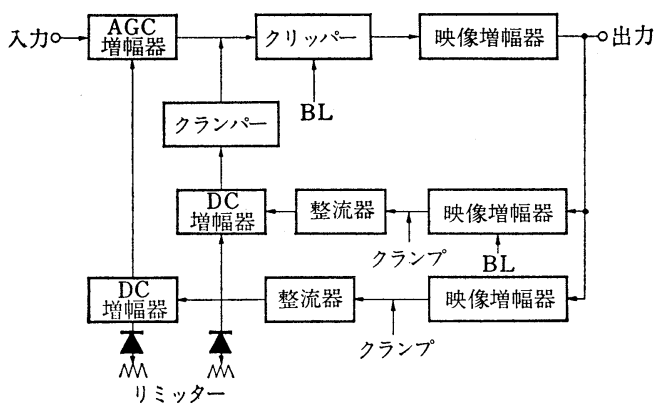

図 6 AGC, ASU 回路系統図

図 7 利得調整
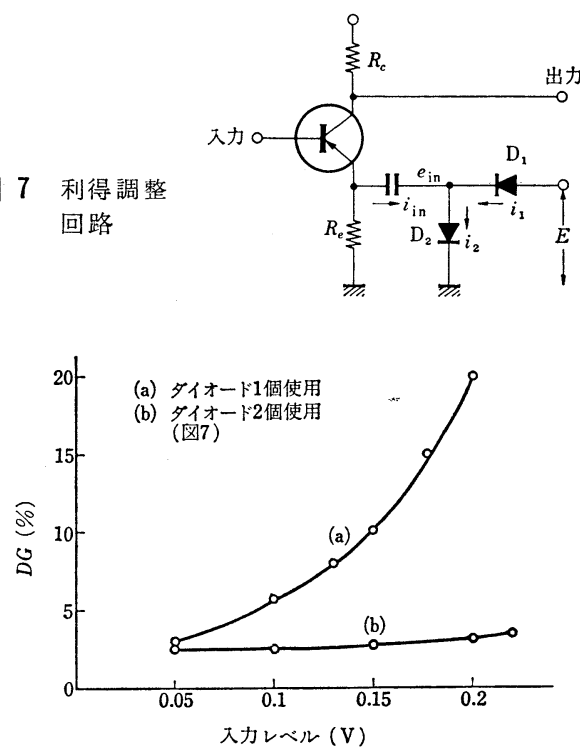

図 8 利得調整回路の直線性

入力 $e_{\text {in }}$ を加えた場合には，各ダイオードを差動的に動 作させるので，ダイオードの等価抵抗は，

$$
R_{d}=\frac{d e_{\mathrm{in}}}{d i_{\mathrm{in}}}=\frac{1}{2 I k \cosh \left(k e_{\mathrm{in}}\right)}
$$

$e_{\text {in }}$ が小さい場合は $\cosh \left(k e_{i_{n}}\right) \fallingdotseq 1$ であるから，等価抵抗 は入力信号に無関係になり, 図 7 において $R_{e} \gg R_{d}$ にと れば, ダイオードの両端の電圧 $E$ を変化することによ り，交流分に影響なく直線性の良い利得調整を行なうこ とができる(図 8 ).

AGC の特性上の問題として, 出力偏差と応答速度の 問題がある. AGC 回路の偏差を少なくするためにはル ープ利得を大きくとればよいが，そのために応答速度が 速くなり, 出力にハンティングが現われて安定度が悪く なるため,てれらを考慮した場合, ある点で妥協する必要 がある. 特にカットインのときハンティングが起とりや すいため, この状態でハンティングをなくすように回路 設計を行なえば, 安定な AGC 回路を得ることができる. 


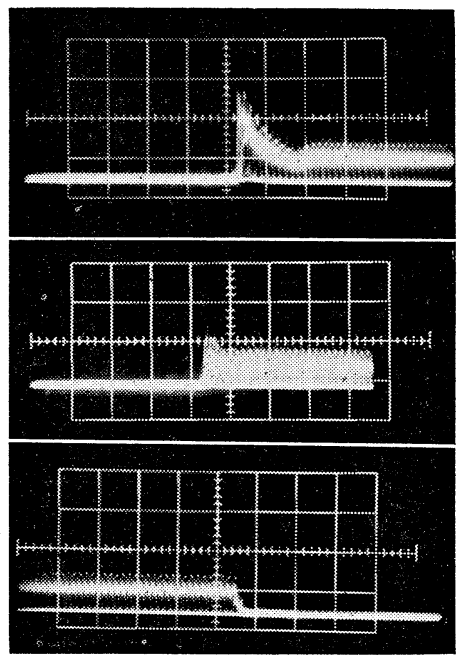

写真 2 応答特性波形 $(0.1 \mathrm{sec} / \mathrm{div}, 0.5 \mathrm{~V} / \mathrm{div})$

写真 2 はカットイン, カットアウトのとき起とる過渡 現象を示したもので, 写真 2 ( a ) は, 映像振幅が零から1. $0 \mathrm{Vp}-\mathrm{p}$ まで変化したとき，(b)は $0.7 \mathrm{Vp}-\mathrm{p}$ までのあの である.（c）はカットアウトの場合で, 過渡的にも, 応答 速度についても闍ないてとを示している. 以上の測定 に当たり図 6 亿示すリミッター回路は動作状態である.

\section{6. $\mathrm{ASU}$}

ビジコンカメラに拉いて, ペデスタルの変動する要素 はターゲット電圧の変化, フィルムの調子, 光量変化な どが上げられる．乙れらによって変動するペデスタルを 従来は手動で調整を行なっていたが，ASU 回路を挿入 することによりその必要がなくなり, 調整が非常に簡易 化されたＡSUを行なう方法としては，ペデスタルク リップレベルを制御する方法と, 黒レベル調整用パルス を制御する方法があるが，後者は極性反転する場合，回 路的に考慮する必要があるので, 極性反転に無関係な前 者が多く用いられている.

ASU 回路の原理を簡単に紹介すると, 図 9 において
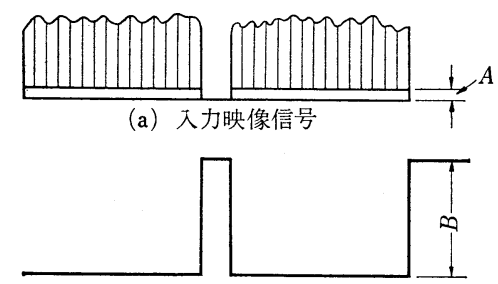

(b) 逆 BL信号

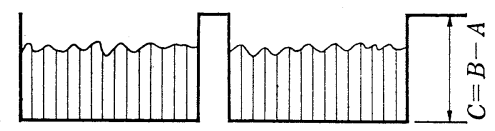

(c) 逆 B L 混合信号
図 9 ASU 回 路に打ける制 御電圧検出波 形
$A$ なる振幅のペデスタルに $B$ なる逆 $\mathrm{BL}$ 信号を混合する と $C$ なる信号が得られる. $B$ が一定值であれば $C$ は $A$ に反比例した電圧として検出され，乙の電圧を整流，増 幅してペデスタルクリップ電圧として使用すれば, ASU 動作を行なわせることができる.

図 9 からあ判断されるように，Aが大きくなるほうは $C=0$ まで検出できるが， $A$ が小さくなるほうは $C=B$ までで, 正規の映像信号は $A$ の值が零または $10 \%$ であ るため, ペデスタルのもぐるほうはループ利得をある程 度大きくとらないと偏差が大きくなる。

この影響は極性反転を行なう場合に著しく，ポジの場 合は黒レベルより黒になることはないが，ネガの場合に AGC, ASU が逆の動作を行なうようになる.すなわち ネガの場合, 映像レベルの変動はペデスタルの変動とし て検出され，ペデスタル変動は映像レベルの変動となる ため, ポジよりもネガのほうがペデスタルの変動が大き く, しかも零よりもむぐることが考えられるので, 偏差 も大きく現われる.

この現象をなくすための手段としては，映写機の絞り を決定し，フィルムを入れない状態でビジコン面に光を 当て，てのときのペデスタルを正規のペデスタルとして セットすれば, これより明るくなることはないので, ヘ デスタルのもぐる現象は防ぐことができる.しかし，乙 の場合はループ利得を必要以上に大きくとらなければな らないので発振を招きやすく，不安定の原因々もなるの で得策ではない。

\section{AGC と ASU の関係}

AGC, ASU は前にも述べたように同一検出点から信 号を取り出し，それぞれの制御回路を通ってコントロー ルを行なっているため, 兩者の間に何の規制るない場合 は，映像信号の種類によっては誤動作の原因となる．乙 のととは BL 信号のみの信号を考えた場合に容易に理解 できることで，乙のために両者の制御動作に応答時間の 差および応答制限回路をもうけ，両者の動作を適当に制 限する必要がある.

制限回路を付加する理由はそのほかにあある。それは AGC の動作範因を広くとることにより, 必要以上に AGC をかけることになり，もともと振幅の小さい映像 まで増幅して，非常に $S N$ 比の悪い映像を送り出すて とになる. ASU 回路についても同様のととがいえる.

\section{8. 自動化系の整流回路}

現在使用されている多くの自動化回路は, その中に整 流回路をふくんでいるが，信号応答の基礎となる部分で あるため, その取扱い方は使用される回路により考虑す 
る必要がある，問題となるのは映像信号を直流に変換す る場合， $\mathrm{p}-\mathrm{p}$ 整流を行なうか，平均值整流を行なうかま たは両者の中間でよいのか， $\mathrm{p}-\mathrm{p}$ 整流を行なう場合はど の程度の信号まで検出するかにかかってくる，必要以上 に細いピーク信号で検出を行なえば他の信号が犠牲にな る場合があり，平均值的な整流を行なえば検出誤差が大 きくなってしまう，以上のととは応答速度とも直接関係 があるため, 現在では実際に機器を使用した状態で決定 せざるを得ない，

\section{ALC, ASC}

ALC，ASC はとあにビジコン自体の出力信号電流を 制御するむので, ASC はビジコンのターゲット電圧また はカソード電圧を入射光量に応じた映像信号の変化分之 して検出して制御し, 出力信号電流を一定に保ち, 最良 の映像を送り出すための回路である.

ALC は映写機側またはカメラ側において，入射光量 を制御してターゲット面照度を一定にする装置で，現在 ではデンシティーフィルターを映写機側で回転させる方 法, 液体の濃度を適当な方法で変化させる方法7などが 実用化されている.

ASC を行なう方法は前にも述べたように，ターゲッ トをコントロールする方法とカソードをコントロールす る方法" があるが，動作原理は双方とあ同じである. タ ーゲットコントロールの場合は, コントロール電圧の変 動が直接プリアンプの入力にかかるため，プリアンプを ふくめた制御系の $f$ 特性を設計上考虑しなければならな いと同時に，ダイナミックレンジを，ASC が挿入され ない場合よりあ大きくとらなければ非直線部分にかかり ，安定度，応答時間などに影響を及ぼす．乙れらのとと を考えた場合に，トランジスタ化されたてとが逆に画質 改善に悪影響を与えるため，ASC の制御範囲を小さく
とらなければならなくなる。

以上のととは応答速度とあ関係があり，ASC におい てはビジコン自体が光導電機構による遅れと, 蓄積容量

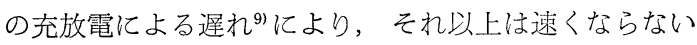
ため, 系の応答速度もこれ以上速くするととはできない．

カソードコントロールは以上のような現象がないので 回路的にはすぐれているが，各電極に供給する電源を別 々にしなければならない欠点がある.

\section{0. む す び}

自動化之特性改善については，今後さらに検討すべき 事項が多い．フィルム画質の統計的な判断も必要であり その点で現業との密接な協力のもとに, 使用実績によっ て決定さるべき未解決分野がある.フィルム製作, 撮 影, 現像, さらに現業の各分野の協力で今後最良の方式 を見いだして行くべきであろう.

終わりに，で指導とご助言を賜わった NHK 演奏設備 部重田副部長, 渡辺氏ならびに NET 竹下副部長の諸氏 に感謝の意を表する.

\section{〔参 考 文 献〕}

1) 中村有光他：垂直アパーチャ補正器の設計, テレビ誌, 18, 4 (1.964) 217

2) 鈴木, 藤村: 電気的補償回路によるピジコンフィルムカメラのイ メージオルシコン画調への近似，テレビ誌， 18, 7 (1964) 425

3) R.G. Neuhauser 他: The Design and Performance of a High -Resolution Vidicon, J. SMPTE, 11 (1962)

4) 後藤: 11/2 インチビジコンカメラの残像特性、テレビ誌, 18,3 (1964) 139

5) 坂井, ビジコン用トランジスタ前置増幅器, テレビ誌, 17,5 (1963) 276

6) 小林秀郎他：トランジスタ式テレシネ投写室および調整装置，放 送技術, 15, 4 (1962) 258

7) 理科学精機：ALC 取扱説明畫

8) S. L. Bendll 他: Automatic Sensitvity Control for Monochrome Film Cameras, Broadcast and Equipment Engineering

9) 日比正男他：ビジコン感度の自動制御, テレビ誌, 16,12(1962) 711

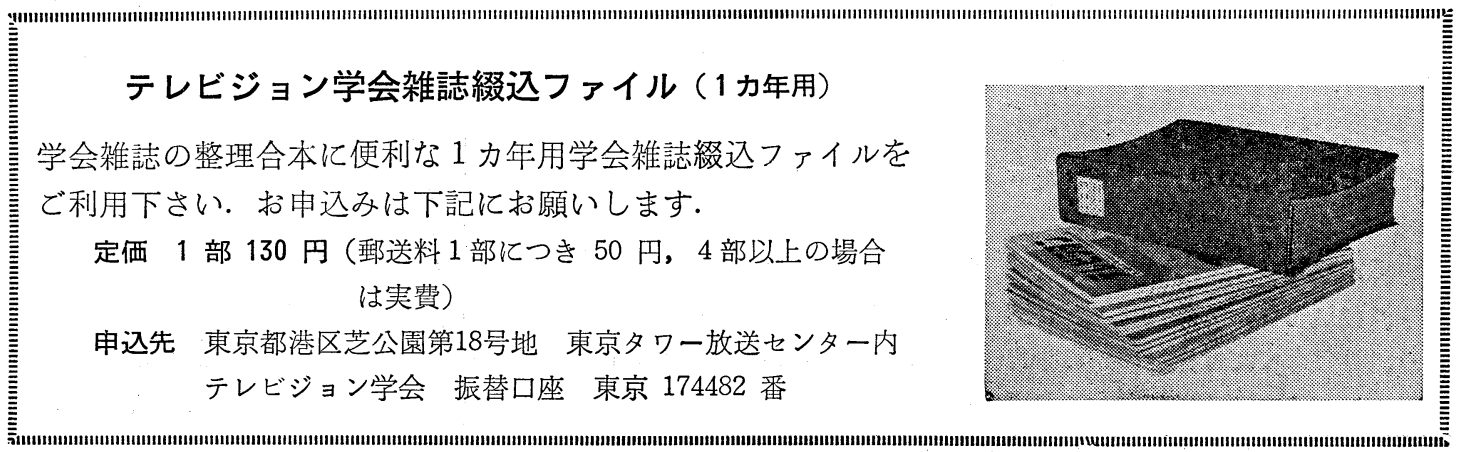

